\title{
Coffee Berry Borer Resistance in Coffee Genotypes
}

\author{
Gustavo Hiroshi Sera*, Tumoru Sera, Dhalton Shiguer Ito, Claudionor Ribeiro Filho, \\ Amador Villacorta, Fabio Seidi Kanayama, Clayton Ribeiro Alegre and Leandro Del \\ Grossi \\ Instituto Agronômico do Paraná; Área de Melhoramento e Genética Vegetal; Rod. Celso Garcia Cid; Km375; C.P.: \\ 481; 86001-970; Londrina - PR - Brasil
}

\begin{abstract}
The aim of this study was to evaluate the coffee germplasm of the Parana Agronomic Institute (IAPAR) for resistance to the coffee-berry-borer. Preliminary field evaluation was performed in August 2004 and the fruits of less damaged genotypes in the field were evaluated under controlled condition with obligated and free choice experiments established in a randomized complete design with three replications. The genotypes were evaluated fifteen days after infestation with one borer per fruit in Petri dishes. The data were analyzed by the Scott-Knott means test at $1 \%$ and by the $\chi^{2}$ test. Statistical analysis indicated that Coffea kapakata, Psilanthus bengalensis, C. eugenioides and genotypes with $\mathrm{C}$. eugenioides genes were resistant. These genotypes presented low frequency of bored grains. C. eugenioides and C. kapakata could present resistance at epicarp level but not in the grain. $\mathrm{P}$. bengalensis could present resistance also in the grains.
\end{abstract}

Key-words: Breeding, Coffea, cultivars, Hypothenemus hampei, Psilanthus

\section{INTRODUCTION}

The coffee berry borer, Hypothenemus hampei (Ferrari) was accidentally introduced to Brazil (Oliveira-Filho, 1927) and has been considered one of the most important coffee pests worldwide. Matiello et al. (2002) reported that this insect was the second pest in importance for arabica coffee (Coffea arabica L.) plantations in Brazil. However, it is the main pest for robusta coffee $(C$. canephora Pierre).

The adult form of $H$. hampei is a small beetle with dark and shiny color. The males possess the same morphological characters as the females, but are smaller with rudimentary wings, and therefore, they do not fly and never leave the fruits. Each male mates, approximately, with ten females inside the fruit. The fertilized female bores the fruit in the disc region, making a gallery through the pulp and after that it bores the seeds (grains), and inside lays the eggs. After hatching, the larvae feed on the seeds, destroying them totally or partially. The reproduction of this insect is higher in high humid environments (Lima et al., 2003).

The direct damage in the yield is the fall of young fruits attacked by the coffee berry borer, destruction of the bored beans that break during hulling, resulting in the reduction of commercial grains. The indirect damage is the bored beans causing the depreciation of the coffee quality (Batista, 1986).

Although there are many studies on chemical, biological and cultural control, coffee breeding for this pest has not been studied due to lack of resistance sources in the Coffea genus and related species. Le Chevalier (1947 cited by Le Pelley,

\footnotetext{
*Author for correspondence: gustavosera@iapar.br
} 
1968) classified the species evaluated in increasing order of attractiveness by the borer as $C$. liberica (practically immune), C. excelsa, C. dybowskii, C. dewevrei, C. arabica and C. canephora. Le Pelley (1968) reported that generally $C$. arabica was more susceptible, followed by $C$. canephora, and $C$. liberica and $C$. excelsa were less attacked, but the preference order was apparently changeable. The resistance and susceptibility reactions of the coffee genotypes can be different, depending on the environmental conditions. According to Matiello et al. (2002), there were no coffee cultivars that were not attacked by this insect and robusta coffee was preferred by the borer. The Dr. Amador Villacorta (personal communication, 2003) reported that $C$. kapakata did not present any borer under field conditions.

The $\alpha$-amylase inhibitor genes, which have potential to promote the resistance to the borer have been tranfered to coffee by genetic transformation, but efficiency has not yet been confirmed in borer control (Jiménez et al., 2000; Valencia et al., 2000; Grossi-de-Sá et al., 2004). Sera and Cotarelli (personal communication, 2004) observed that under field conditions, some species of coffee (C. eugenioides and C. kapakata) did not present any infestation of H. hampei when compared with $C$. canephora and $C$. arabica.

The aim of this study was to identify the resistance sources to $H$. hampei in different species and genotypes of coffee in the IAPAR germplasm bank by field and laboratory evaluations.

\section{MATERIALS AND METHODS}

\section{Field evaluations}

A preliminary evaluation in the field at germplasm bank of IAPAR was accomplished on August $5^{\text {th }}$ 2004, before making the confinement and free choice laboratory experiments. The evaluated genotypes in the field evaluation were: Coffea eugenioides x $C$. dewevrei (T1), " $C$. eugenioides 18-6" (T2), "C. eugenioides LAB" (T3), $C$. eugenioides x "Mundo Novo" tetraploid (T4), $C$. congensis (T5), C. kapakata (T6), Psilanthus bengalensis (T7), $C$. canephora cv. Nemaya (T12), C. dewevrei (T13) and C. arabica x " $C$. canephora var. robusta (4x)" or "Arabusta" (T14). IAPAR (Londrina - PR, Brazil) is located at $23^{\circ}$ $22^{\prime}$ latitude south and at $51^{\circ} 10^{\prime}$ ' longitude west, altitude 585 meters. The annual average precipitation is $1610 \mathrm{~mm}$, the annual average temperature is $20.8{ }^{\circ} \mathrm{C}$ and the relative air humidity is $71 \%$. At IAPAR's germplasm bank there was no chemical borer control.

The percentage of bored fruits $(\% \mathrm{BF})$ was used to evaluate the resistance reaction of the genotypes. In this evaluation, the majority of the berries (90\%) were green with completely formed endosperm or ripened fruits. The sampling of the fruits was randomized in different positions of the plant.

\section{Laboratory experiments}

The experiments were carried out without incidence of direct light on August $10^{\text {th }}, 2004$ and evaluated fifteen days after the infestation. Benassi (2000) reported that after five days of infestation with borers in $C$. canephora fruits, all the females had penetrated in the endosperm.

To test the resistance to borer, berries without this insect of the genotypes that presented low incidence in the field evaluations were collected in the field. These berries were dipped in melted paraffin to prevent the entrance of the borer through the fruit base due to fruit skin injury at the moment of collecting the fruits. They were protected with paraffin from the base of the fruit to half of the length of the fruit. Then, the fruits were placed in Petri dishes $(8.5 \mathrm{~cm}$ in diameter and 1.1 $\mathrm{cm}$ in height) with $20 \mathrm{~g}$ of sterilized sand to facilitate the movement of the borer in the dishes. The resistance was tested with only one genotype per dish (confinement test) and another test with two genotypes (one resistant and one susceptible tested in the confinement test $=$ free choice test) in the same dish. In both tests, one borer was placed per fruit. After placing inside the petri dishes, these were closed. The majority of the fruits (95 $\%$ ) used in the confinement and free choice test were green with completely formed endosperm or ripened fruits and around $5 \%$ were at the overriped berry stage.

\section{Confinement test}

First, the confinement test was carried out to identify the susceptible and resistant genotypes in order to perform the free choice test later. The treatments used in the confinement test were: $\mathrm{T} 1$, T2, T3, T4, T5, T6, T7, 'Pacas' $\mathrm{x}$ 'Maragogipe' (T8), "Catuaí Semperflorens" (T9), (C. dewevrei x C. arabica) $4 \mathrm{x}=$ "Piatã" (T10), "Mundo Novo" (T11) and T12. 
The experiment (confinement test) was performed in a randomized complete design with three replications and twelve fruits per plot. For the variable percentage of fruits not bored (\% FNB), the Cochran test (Gmax) was used to verify the variance homogeneity. The simple linear regression coefficients (b) between the logaritm of the means and the logaritm of the variances were estimated to indicate the transformation. However, in this study, the variances equal to zero were found in treatments $\mathrm{n}^{\circ} 2,4$ and 7 , hence, the logaritm values could not be attained. Thus, all the variances were added to index 0.5 for determining the coefficient $\mathrm{b}$ subsequently. The transformation used was 1/ $\mathrm{x}$. The statistical program Genes (Cruz, 2001) was used for the analysis of variance at the level of plot mean to compare the means by the Scott Knott test at $1 \%$ for the variable \% FNB and to estimate the genotypic determination coefficient. For the variable, percentage of fruits with penetration in the epicarp but with grains not bored (\% BF-GNB), the $\chi^{2}$ test was used to verify the differences between the genotypes.

\section{Free choice test}

The free choice tests were: $\mathrm{T} 1$ versus $\mathrm{T} 5, \mathrm{~T} 2$ versus $\mathrm{T} 5, \mathrm{~T} 4$ versus $\mathrm{T} 5, \mathrm{~T} 3$ versus $\mathrm{T} 12, \mathrm{~T} 6$ versus $\mathrm{T} 12$ and $\mathrm{T} 7$ versus $\mathrm{T} 12$. The genotypes $\mathrm{T} 5$ and
T12 were used as susceptible standards. Twenty berries of one susceptible genotype and twenty of one resistant genotype were placed in the same Petri dishes, in a randomized complete design with three replications, totalling sixty fruits per genotype. The comparisons between the genotypes were performed by the $\chi^{2}$ test at $1 \%$ in the $1: 1$ hypothesis, using as variables the amount of bored fruits $(\mathrm{BF})$ and amount of fruits with penetration in the epicarp but with grains not bored (BF-GNB). In this study, the variable bored fruits (BF) were considered those fruits with epicarp and grain penetrations.

\section{RESULTS AND DISCUSSION}

\section{Field evaluation}

With this preliminary evaluation, it was possible to indicate that the treatments T1, T2, T3, T4, T6 and T7 presented higher field resistance than the treatments T5, T12, T13 and T14, and the last one was the most susceptible (Table 1). C. dewevrei presented high infestation of $H$. hampei under field conditions and did not confirm the suggestion by Fazuoli (2004), which indicated the possibility of this species to present more difficulty of penetration by the borer due to thicker endocarp.

Table 1 - Percentage of bored fruits (\% BF) in Coffea germplasms of the field evaluation accomplished in August 2004 at IAPAR (Londrina - PR - Brazil).

\begin{tabular}{lcc}
\hline Genotypes & Number of fruits evaluated & \% BF \\
\hline Coffea eugenioides x C. dewevrei (T1) & 538 & 0.00 \\
C. kapakata (T6) & 463 & 0.00 \\
Psilanthus bengalensis (T7) & 995 & 0.10 \\
"C. eugenioides LAB" (T3) & 284 & 1.41 \\
"C. eugenioides" x "Mundo Novo" tetraploid (T4) & 450 & 4.00 \\
"C. eugenioides 18-6" (T2) & 576 & 7.29 \\
C. canephora cv. Nemaya (T12) & 408 & 12.01 \\
C. congensis (T5) & 1084 & 17.53 \\
C. dewevrei" (T13) & 600 & 25.33 \\
"C. arabica" " "C. canephora tetraploid" (T14) & 600 & 55.83 \\
\hline
\end{tabular}

\section{Confinement test}

From the data of the field evaluations, the genotypes that presented high field resistance and others considered susceptible were used to accomplish the confinement test. The Cochran test (Gmax) indicated that homogeneity of the variances for variable $\%$ FNB existed. The experimental variation coefficient was $16.88 \%$ indicating good experimental precision.
For the means test of the variable \% FNB, the treatments were classified in three groups ("a", "b" and "c"). Group "a" was considered resistant and the groups "b" and "c" as susceptibles. 'Pacas' $x$ 'Maragogipe' was more susceptible than the other susceptible genotypes, probably, due to some experimental error or due to minor genes effect (Table 2). 
Table 2 - Results of the confinement test with the average percentage of fruits not bored (\% FNB) and average percentage of fruits with penetration in the epicarp but with grains not bored (\% BF-GNB) of coffee genotypes evaluated 15 days after the infestation with one borer per fruit.

\begin{tabular}{lcc}
\hline Genotypes & \% FNB & \% BF-GNB \\
\hline Psilanthus bengalensis (T7) & $100 \mathrm{a}$ & $33.34 \mathrm{a}$ \\
C. eugenioides X "Mundo Novo" tetraploid (T4) & $100 \mathrm{a}$ & $0.00 \mathrm{~b}$ \\
"C. eugenioides 18-6" (T2) & $100 \mathrm{a}$ & $13.33 \mathrm{~b}$ \\
C. eugenioides X C. dewevrei (T1) & $97.14 \mathrm{a}$ & $3.81 \mathrm{~b}$ \\
"C. eugenioides LAB" (T3) & $95.07 \mathrm{a}$ & $1.90 \mathrm{~b}$ \\
C. kapakata (T6) & $90.39 \mathrm{a}$ & $0.00 \mathrm{~b}$ \\
"Catuaí Semperflorens" (T9) & $75.24 \mathrm{~b}$ & $0.00 \mathrm{~b}$ \\
C. congensis (T5) & $73.34 \mathrm{~b}$ & $0.00 \mathrm{~b}$ \\
C. dewevrei X C. arabica (T10) & $73.33 \mathrm{~b}$ & $0.00 \mathrm{~b}$ \\
"Mundo Novo" (T11) & $67.62 \mathrm{~b}$ & $0.00 \mathrm{~b}$ \\
C. canephora cv. Nemaya (T12) & $61.28 \mathrm{~b}$ & $0.00 \mathrm{~b}$ \\
'Pacas'x 'Maragogipe' (T8) & $48.01 \mathrm{c}$ & $1.93 \mathrm{~b}$ \\
\hline
\end{tabular}

${ }^{(1)}$ Means followed by the same letter did not differ by the Scott-Knott test at $1 \%$.

${ }^{(2)}$ Means followed by the same letter did not differ by the $\chi^{2}$ test at $1 \%$.

The group of resistant genotypes included: $C$. eugenioides x $C$. dewevrei, "C. eugenioides 18-6", "C. eugenioides LAB", C. eugenioides x "Mundo Novo" tetraploid, C. kapakata and P. bengalensis. The same genotypes that presented field resistance also presented resistance in the confinement test. The resistance to borer of the treatments 1 and 4 came from gene (s) of C. eugenioides.

Some genotypes carrying $C$. eugenioides genes presented partial resistance in the field evaluations, including all types of fruits but in the confinement test using only intact fruits, the data indicated complete resistance. In the field evaluation, the treatments $\mathrm{T} 2, \mathrm{~T} 3$ and $\mathrm{T} 4$ presented 7.29, 1.41 and $4.00 \%$ bored fruits, respectively. In the confinement test, the treatments $\mathrm{T} 1$ and $\mathrm{T} 3$ with $C$. eugenioides genes presented 2.86 and $4.93 \%$ bored fruits, respectively, while $C$. kapakata (T6) presented $9.61 \%$. This partial resistance could be associated with several factors. One of the hypotheses is that fruits with epicarp damaged by the insects, diseases and other factors facilitate the penetration of the borer under field conditions and in laboratory tests. It was observed that only damaged fruits of resistant plants in the field presented borer penetratrion.

At fifteen days after berry borer infestation in the confined evaluation observed that fruits of resistant plants with wrinkled and dull epicarp and with the appearance of nourishment deficiency were penetrated, although they had a normal appearance at infestation. This could indicate less repellent effect or more attractive effect due to the damages in the fruits. The plants of these fruits of
C. kapakata and genotypes carrying $C$. eugenioides genes, were probably badly nourished, with damage provoked by other insects and diseases or, mainly, with low water potential provoked by drought at this time. C. canephora cv. Nemaya presented higher vegetative vigor and is more tolerant to droght than other genotypes. Abnormal fruits in C. canephora cv. Nemaya were not observed.

Before infestation with borers, all the fruits were apparently normal, but few days after infestation, some whole fruits (normal) became dull or wilted (abnormal). Before infestation, it was observed that some fruits were shinier, probably, with a waxier surface. These fruits presented resistance in the resistant coffee trees in the field, while the abnormal fruits were susceptibles. New studies should be carried out to verify whether the resistance of these fruits was due to this waxiness. The occurrence of dull fruits was probably due to malnourishment or low water potential of the plant caused by the drought that was not observed in 'Nemaya', as reported previously.

Malnourishment and water shortage may not affect resistance when the fruit is still on the plant. The available water and nutrients are interrupted when the fruits are detached from the plants to be used in the confinement test. This could provoke the wrinkling and oxidation of the fruits. Thus, to simulate the field conditions in the laboratory tests, it is necessary to collect the fruits of plants with good nourishment, health and when necessary, to irrigate the plants. An alternative to prevent these experimental errors due to the 
detachment of the fruits would be infestation in the field and to consider in the evaluations only the fruits without damaged epicarp, healthy and wellnourished.

Results showed that few fruits were abnormal. This could be due to that the climatic conditions were good one month before the fruit sampling and evaluations and the plants were more balanced physiologically. The average of the temperature and relative air humidity and total precipitation in July 2004 were $16.2{ }^{\circ} \mathrm{C}\left(\max =21.8^{\circ} \mathrm{C}\right.$; $\min =$ $\left.11.9{ }^{\circ} \mathrm{C}\right), 76.9 \%$ and $113.8 \mathrm{~mm}$, respectively. If the evaluation had been accomplished in September 2004 the frequency of abnormal fruits might have been higher, because August 2004 was more drier. In August 2004, these parameters were $18.9{ }^{\circ} \mathrm{C}\left(\max =26.8{ }^{\circ} \mathrm{C} ; \min =12.0{ }^{\circ} \mathrm{C}\right), 55.6 \%$ and $0 \mathrm{~mm}$, respectively. Thus, would probably be high incidence of abnormal fruits with more fruit borers in other experiments if the climatic conditions and plant nutrition were poor.

C. eugenioides is a diploid species $(2 \mathrm{n}=2 \mathrm{x}=22$ chromosomes) and C. arabica var. Mundo Novo is tetraploid $(2 \mathrm{n}=4 \mathrm{x}=44$ chromosomes $)$, thus, infertile triploids would be derived from the crossing between these two species. These would only be fertile if $C$. eugenioides was tetraploid. Then, treatment 4 (C. eugenioides $\mathrm{x}$ "Mundo Novo" tetraploid) is very valuable, because besides producing fertile progenies, it presents "Mundo Novo" genes, which presents many advantages such as high yield and quality. It is necessary to accomplish backcrosses with this genotype aiming to incorporate genes of $C$. arabica cultivars.

The $P$. bengalensis presented $33.34 \%$ of the fruits with penetration in the epicarp but without penetration in the grain. This frequency was statistically different in relation to other genotypes. Thus, the $P$. bengalensis resistance could be also in the coffee grain.

T5 (C. congensis) and T12 (C. canephora cv. Nemaya) confirmed the field susceptibility in this test because $27 \%$ and $39 \%$ of bored grains were observed, respectively. Hence, these two genotypes were used in free choice test together with resistant genotypes.

The genotypic determination coefficient for the FNB was $87.32 \%$ indicating that there was a high possibility of success in the selection of genotypes resistant to the borer and that the resistance must be controlled by few genes.

\section{Free choice test}

Only test $\mathrm{T} 7$ versus $\mathrm{T} 12$ presented significant difference at $1 \%$ for $\mathrm{BF}$ and $\mathrm{BF}-\mathrm{GNB}$ variables. This indicated that $P$. bengalensis presented resistance in the grains (Table 3 , Table 4), because all the borers that perforated the epicarp of $P$. bengalensis did not perforate the grain.

The treatments T1, T2, T3, T4 and T6, resistant in field evaluations and in the confinement test, presented bored grain frequency similar to the susceptible genotypes T5 (C. congensis) and T6 (C. canephora cv. Nemaya). When the attractiveness effect of $C$. congensis (T2 vs T5) was compared with $C$. canephora cv. Nemaya (T3 vs T12), on $C$. eugenioides, there was an indication that the effect of Nemaya was higher than the $C$. congensis effect (Table 3). A similar effect occurred when $C$. kapakata was tested with C. canephora cv. Nemaya, annulling completely the high resistance of $C$. kapakata. Nemaya presented a greater percentage of bored fruits in the confinement test than $C$. congensis, but not statistically different. Volatile substances of the $C$. congensis and Nemaya fruits might have changed the resistance reaction of $\mathrm{T} 1, \mathrm{~T} 2, \mathrm{~T} 3, \mathrm{~T} 4$ and $\mathrm{T} 6$, inducing the penetration in the fruits.

Table $3-\chi^{2}$ test at $1 \%$ for the variable amount of bored fruits (BF) in the free choice test, evaluated 15 days after infestation with one borer per fruit.

\begin{tabular}{|c|c|c|c|c|}
\hline Free choice tests & & & $\mathbf{B F}^{(1)}$ & $\chi^{2}$ \\
\hline C. eugenioides $\mathrm{x} C$. dewevrei (T1) & vs & C. congensis (T5) & 3 vs 5 & $0.500^{\text {n.s. }}$ \\
\hline "C. eugenioides 18-6" (T2) & vs & C. congensis (T5) & 4 vs 3 & $0.142^{\text {n.s. }}$ \\
\hline C. eugenioides x "M. Novo"/ 4x (T4) & vs & C. congensis (T5) & 1 vs 4 & $1.800^{\text {n.s. }}$ \\
\hline "C. eugenioides LAB" (T3) & vs & C. canephora cv. Nemaya (T12) & 16 vs 12 & $0.571^{\text {n.s. }}$ \\
\hline C. kapakata (T6) & vs & C. canephora cv. Nemaya (T12) & 14 vs 14 & $0.000^{\text {n.s. }}$ \\
\hline P. bengalensis $(\mathrm{T} 7)$ & vs & C. canephora cv. Nemaya (T12) & 0 vs 9 & $9.000 * *$ \\
\hline
\end{tabular}

(1) In this experiment twenty fruits were evaluated of one resistant genotype and twenty fruits of one susceptible genotype in the same petri dishes, with three replications, totaling sixty fruits per genotype. BF = bored fruits with epicarp and grain penetrations. 
Table $4-\chi^{2}$ test at $1 \%$ for the variable amount of fruits with penetration in the epicarp but with grains not bored (BF-GNB) in the free choice test, evaluated 15 days after infestation with one borer per fruit.

\begin{tabular}{|c|c|c|c|c|}
\hline \multicolumn{3}{|l|}{ Free choice tests } & \multirow{2}{*}{$\begin{array}{c}\text { BF-GNB }^{(\mathbf{1})} \\
0 \text { vs } 1\end{array}$} & \multirow{2}{*}{$\frac{\chi^{2}}{1.00^{\text {n.s. }}}$} \\
\hline C. eugenioides $\mathrm{x} C$. dewevrei (T1) & vs & C. congensis (T5) & & \\
\hline “C. eugenioides 18-6" (T2) & vs & C. congensis (T5) & 0 vs 1 & $1.00^{\text {n.s. }}$ \\
\hline C. eugenioides x "M. Novo"/ 4x (T4) & vs & C. congensis $(\mathrm{T} 5)$ & 1 vs 1 & $0.00^{\text {n.s. }}$ \\
\hline “C. eugenioides LAB” (T3) & vs & C. canephora cv. Nemaya (T12) & 0 vs 0 & $0.00^{\text {n.s. }}$ \\
\hline C. kapakata (T6) & vs & C. canephora cv. Nemaya (T12) & 0 vs 0 & $0.00^{\text {n.s. }}$ \\
\hline P. bengalensis (T7) & vs & C. canephora cv. Nemaya (T12) & 9 vs 0 & $9.00 * *$ \\
\hline
\end{tabular}

(1) In this experiment twenty fruits were evaluated of one resistant genotype and twenty fruits of one susceptible genotype in the same Petri dishes, with three replications, totaling sixty fruits per genotype.

After penetrating the epicarp, $H$. hampei penetrated freely in the grains. Thus, probably, the C. kapakata and C. eugenioides resistance gene (s) to the borer was only expressed in the epicarp. $C$. eugenioides, $C$. kapakata and $P$. bengalensis could have presented resistance in the epicarp associated to volatile substances.

The effect of $C$. canephora $\mathrm{cv}$. Nemaya on $C$. eugenioides and $C$. kapakata, annulling the resistance of these two genotypes, did not occur in P. bengalensis (Table 3). In some fruits, the death of the borer was observed and in others, the epicarp was perforated, but, no borer was in the grain. This indicated the absence of some important substance to the borer in $P$. bengalensis grains or the presence of antagonistic substances to the borer. It could be possible that $H$. hampei did not eat the $P$. bengalensis grains, because there was no caffeine in this species. Ondarza and Gutierrez (1996) reported that the caffeine was of great importance for borer attraction. However, Guerreiro-Filho and Mazzafera (2003) concluded that the caffeine did not increase the coffee resistance to $H$. hampei.

As reported previously, $C$. eugenioides and $C$. kapakata probably only presented some repellent or not attractive volatile substance or antagonistic substances to $H$. hampei in the epicarp and absence of antagonistic substance in the grain. Giordanengo et al. (1993) showed that in smellmeter tests that the volatile substances eliminated by the fruits influenced the borer choice. Ondarza and Gutierrez (1996) observed that the coffee berry borer was attracted by the kairomones and other volatile substances released by the fruits. Costa (2002) found attractiveness of the $\beta$-pineno volatile composition in the borer females and signals of repellence of the limoneno volatile composition in $H$. hampei. Mathieu et al. (1998) reported that these two composites were present at high concentration in ripe berries and found differences in the volatile composition when compared C. canephora and C. arabica.

It would be necessary to transfer the $C$. eugenioides, $C$. kapakata and $P$. bengalensis resistance gene (s) to commercial varieties. The resistance gene of $P$. bengalensis, is probably different from the $C$. eugenioides and $C$. kapakata gene (s).

Lima et al. (2003) reported the possibility of using volatile substances such as $\beta$-pineno to sintetize more attractive traps than those used currently with a mixture of etanol: metanol, or to use the repellents such as limoneno in sprayings. The antagonistic substance (s) of the $P$. bengalensis fruit have potential to be used as botanical insecticidal against $H$. hampei. The attractive volatile substances, more in $C$. canephora cv. Nemaya and 'Pacas' $\mathrm{x}$ 'Maragogipe' than in $C$. arabica genotypes, could be used better at "IAPAR borer trap" (Villacorta et al., 2001; IAPAR, 2008) than using $C$. arabica fruit extract. These resistant genotypes must be studied in diverse study areas aiming at to analyze which volatile substances of the fruit affect the resistance of these coffees and which gene (s) are responsibles for the $C$. eugenioides, $C$. kapakata and $P$. bengalensis resistance. The gene of $P$. bengalensis has potential for cloning for use in genetic transformation, therefore, this species is very different from $C$. arabica. The association of two resistance genes can hinder the formation of new borer biotypes that defeat the resistance genes of the coffee. The possibility of using the fruits and leaves of the P. bengalensis as a botanical insecticide and the greater attractiveness of some genotypes to use substances of these in borer traps should be studied. Among three genotypes, it is necessary to evaluate the reproduction factor of $H$. hampei and the exact degrees of resistance and tolerance of each genotype. 


\section{ACKNOWLEDGEMENTS}

The authors thank the Paraná Agronomic Institute (IAPAR).

\section{RESUMO}

O objetivo deste trabalho foi identificar fontes de resistência genética a $H$. hampei em diferentes espécies de café do banco de germoplasma do Instituto Agronômico do Paraná (IAPAR), Londrina, PR. Foram realizadas avaliações preliminares de campo, para posterior testes de confinamento e de livre escolha, em laboratório, instalados em delineamento inteiramente casualizado com três repetições. Os genótipos foram avaliados quinze dias após a infestação com uma broca por fruto em placas de petri. Os dados foram analisados pelo teste de médias Scott-Knott a $1 \%$ e pelo teste de $\chi^{2}$. Foi observado que $C$. eugenioides, $C$. kapakata e $P$. bengalensis constituem importantes fontes de resistência à broca, pois apresentaram menor frequiência de grãos brocados. Os dois primeiros podem apresentar substâncias voláteis antagônicas à broca na casca e a resistência de $P$. bengalensis pode estar também no grão.

\section{REFERENCES}

Batista, M. (1986), Efeitos de diferentes índices de infestação pela broca-do-café Hypothenemus hampei (Ferrari, 1867) (Coleoptera: Scolytidae) no peso e na classificação do café pelo tipo e pela bebida. MSc Thesis, Escola Superior de Agricultura de Lavras. 67 pp.

Benassi, V. L. R. M. (2000), Aspectos biológicos da broca-do-café, Hypothenemus hampei (Ferrari, 1867) (Coleoptera: Scolytidae), em Coffea canephora. Paper presented at $1^{\text {st }}$ Simpósio de pesquisa dos cafés do Brasil, Poços de Caldas, MG. Embrapa Café/ MINASPLAN, Brasília. pp 1181-1184.
Costa, F. G. (2002), Avaliação de semioquímicos do café para seu emprego em programas de controle e monitoramento da broca do café, Hypothenemus hampei (Coleoptera: Scolytidae). Dissertation, Universidade Federal de Viçosa.

Cruz, C. D. (2001), Programa Genes: versão Windows; aplicativo computacional em genética e estatística. UFV, Viçosa.

Fazuoli, L. C. (2004), Melhoramento genético do cafeeiro. Paper presented at $10^{\text {th }}$ Reunião itinerante de fitossanidade do Instituto Biológico, Mococa, SP. pp 2-28.

Giordanengo, P.; Brun, L. O.; Frerot, B. (1993), Evidence for allelochemical attraction of the coffee berry borer, Hypothenemus hampei, by coffee berries. J Chem Ecol, 19:763-769

Grossi-de-Sá, M. F.; Pereira, R. A.; Barros, E. V. S. A. et al (2004), O uso de inibidores de $\alpha$-amilases no controle da broca-do-café. Paper presented at $1^{\text {st }}$ Workshop internacional sobre o manejo da broca-docafé, Londrina, PR. IAPAR/ SEAB, Londrina. pp 24.

Guerreiro-filho, O.; Mazzafera, P. (2003), Caffeine and resistance of coffee to the berry borer Hypothenemus hampei (Coleoptera: Scolytidae). J Agric Food Chem, 51(24):6987-6991.

Instituto Agronômico do Paraná. (2008), Armadilhas IAPAR para o manejo da broca-do-café. IAPAR, Londrina. $6 \mathrm{pp}$.

Jiménez, A. V.; González, M. T.; Bustillo, A. E. (2000), Los inhibidores de amilasas como alternativa en la produccion de café resistente a la broca. Paper presented at $3^{\text {rd }}$ International seminar on biotechnology in the coffee agroindustry, Londrina, Brazil. IAPAR/IRD, Londrina. pp 283-289.

Le Pelley, R. H. (1968), Collembola and Coleoptera. Pests of coffee, pp 99-178.

Lima, E. R.; Ambrogi, B. G.; Costa, F. G. et al (2003), Emprego de semioquímicos no manejo de pragas do café. In: Zambolim L. (ed) Produção integrada de café. UFV, Viçosa, pp 47-66.

Matiello, J. B.; Santinato, R.; Garcia, A. W. R. et al (eds) (2002) Cultura de café no Brasil - novo manual de recomendações. $387 \mathrm{pp}$.

Mathieu, F.; Malosse, C.; Frerot, B. (1998), Identification of the volatile components released by fresh coffee berries at different stages of ripeness. $J$ Agric Food Chem, 46:1106-1110. 
Oliveira-Filho, M. L. de (1927), Contribuição para o conhecimento da broca do café Stephanoderes hampei (Ferrari,1867), São Paulo, Sec. Agri. Com. Obr. Publ. 20, 9p.

Ondarza, R. N.; Gutierrez, M. A. (1996), Kairomone effect of extracts from Coffea canephora over Hypothenemus hampei (Coleoptera: Scolytidae). Environmental Entomology, 25(1):96-100.

Valencia, A.; Bustillo, A. E.; Ossa, G. E. et al (2000), Amylases of the coffee berry borer (Hypothenemus hampei) and their inhibition by two plant amylase inhibitors. Insect Biochem and Molec Biol, 30: $207-$ 213.
Villacorta, A.; Possagnolo, A. F.; Silva, R. Z.; Rodrigues, P. S. (2001), Um modelo de armadilha com semioquímicos para o manejo integrado da broca do café Hypothenemus hampei (Ferrari) no Paraná. Paper presented at $2^{\text {nd }}$ Simpósio de Pesquisa dos Cafés do Brasil, Vitória, ES. Embrapa Café, Brasília. pp 141.

Received: May 02, 2007; Revised: May 08, 2008; Accepted: May 22, 2009 